Journal of CORPORATE RESPONSIBILITY

AND LEADERSHIP

CONTEMPORARY CHALlENGES

in CoRporate Social Responsibility

\title{
Community Involvement in Pharmaceutical Companies in Poland
}

DOI: http://dx.doi.org/10.12775/JCRL.2016.022

\author{
MaRTYNA KRUSZYŃSKA \\ The Department of Health Care Management, \\ Medical University of Łódź, Poland \\ e-mail: martyna.kruszynska@gmail.com
}

\begin{abstract}
Aim: The aim of this article is to identify measures in the area of community involvement undertaken by pharmaceutical companies operating in Poland (listed in the IMS Health 2010 ranking of TOP 30 corporations in the pharmaceutical market). Moreover, methods for communicating these measures are also analysed. Methodology: The study covered analysis of Polish-language websites of pharmaceutical companies listed in the TOP 30 ranking. In the case of absence of data on community involvement on a given company website, additional online research with the use of subject terms and Google Search was employed.

Main findings: Of all the 30 companies subjected to the study, 4 companies did not have a section dedicated to corporate social responsibility on their websites, whereas 5 enterprises provided information on community involvement only on a company website in a language other than Polish. The dominant form of community involvement initiatives is financial support (predominantly in the form of donations). Companies also support local communities with aid in-kind and corporate volunteering. Communication of undertaken measures takes a form of the stakeholder information strategy - a company is interested in disseminating information on the actions taken without its stakeholders actively participating in the process.

Implications: Pharmaceutical companies operating in Poland should engage in activities targeted at local communities to a greater extent. Managers of pharmaceutical companies should be made aware of the benefits of using diverse forms of these measures, being at the same time encouraged to continuously expand initiatives already taken in this regard.
\end{abstract}


Keywords: corporate community involvement, pharmaceutical companies.

\section{Introduction}

In management activities conducted by organisations, CSR is currently regarded as one of the most up-to-date and promising business strategies (Sikorska, 2010, p. 143). The most often listed advantages of using the CSR concept by organisations involve improved competitiveness, reduced costs, improved customer relationship, as well as enhanced company innovation (Koneczna, 2014, p. 5). Despite the potential benefits arising from undertaken social responsibility initiatives, according to the report titled Ocena stanu wdrożenia standardów społecznej odpowiedzialności biznesu (Assessment of the implementation status of corporate social responsibility standards) dated as of 2011, only one third of business representatives in Poland have heard about the term 'corporate social responsibility'. The authors of the study focused primarily on the relations between the familiarity with this term and the size of a corporation. The concept was reported as familiar by $70 \%$ large companies, 50\% medium-sized companies, 36\% small companies and only $26 \%$ micro-businesses. In the light of the report findings, the declared common familiarity with the idea of CSR does not translate into its assumptions being thoroughly understood by managers (Millward Brown SMG/KRC and PwC, 2011).

Corporate community involvement (CCI) covers initiatives for local communities undertaken by organisations. The notion of CCI has a narrower meaning than corporate social responsibility, since the undertaken measures are targeted at a single group of stakeholders of a given organisation, i.e. a local community. The community involvement is one of the most visible manifestations of corporate social responsibility in a given organisation. As for the abovementioned report on the implementation of corporate social responsibility standards in Poland, of all the companies declaring to have an established CSR program, 36\% pursued community involvement by means of charity (sponsoring, financing local initiatives, outreach), whereas $28 \%$ reported collaboration with local institutions (Millward Brown SMG/KRC and PwC, 2011).

In 2003, Foundation for Social Communication released a report regarding a study on the attitudes of consumers and social opinion leaders towards the idea of corporate social responsibility, conducted for the 
first time in Poland. Consumers consider pharmaceutical companies as one of most associated with social welfare. This view might stem from the fact that these companies provide 'socially useful' products (medications, medical equipment) as opposed to products provided by tobacco and alcohol companies, which were regarded as least considered with social welfare (Foundation for Social Communication, 2003, p. 9).

The aim of this article is to determine whether pharmaceutical companies operating in Poland (listed in the ranking of TOP 30 corporations in the pharmaceutical market in 2010 by IMS Health) undertake community involvement initiatives. In order to achieve this aim, the author conducted a review of Polish-language websites run by companies subjected to the study. The obtained results allowed the author to identify forms of the undertaken community involvement initiatives and to analyse the implemented methods for communicating social responsibility.

\section{Corporate Community Involvement and its forms}

Corporate community involvement covers pro-social activity of a given enterprise that aims at mitigating problems arising in the community in which the enterprise operates (cf. Rudnicka, 2010, p. 110). Rok (2004, p. 46) distinguishes four levels of corporate community involvement, namely:

- basic economic activity - producing goods and services by a company that are purchased by members of a given community, creating employment on the local labour market, collaborating with partners. These measures undoubtedly contribute to social growth, yet are not officially regarded as social responsibility initiatives;

- commercial measures in social context - undertaken by an organisation with the aim to achieve commercial success while ensuring benefits for the local community (development of regional infrastructure, increased employment). These most often take the form of cooperating with local authorities or non-profit organisations;

- investments for local communities - long-term activities aiming at solving specific issues within the local community in which a given company operates. The issue is selected by the management with respect to the significance of a given issue to the interest of the company, as well as the possibility to strengthen its reputation. Activities 
of this sort are beneficial to the company in the long term, leading to a creation of a society that exhibits traits desired by the organisation (e.g. considerable pro-health awareness or environmental awareness);

- philanthropic activities - the highest level of corporate community involvement consisting in tangible and intangible assets being allocated by the company for specific purposes. The priority here is the benefits brought to a given community (company business objectives are not that important/are not taken into account whatsoever).

Each of the above mentioned level of CCI may take various forms. The most popular forms of community involvement initiatives include, as listed by Gołaszewska-Kaczan (2009, p. 104):

- financial support - one of the basic forms of involvement used nowadays by enterprises. Beneficiaries receive from a given company a specified amount of money for financing a pre-determined goal (at times unspecified). In return for help, the benefactor may often enjoy tax advantages. The freedom of spending of the received funds makes it a preferred form among beneficiaries. Large companies increasingly often decide to establish a corporate foundation that would take on the responsibilities related to offering donations;

- aid in-kind - the company lends or provides free-of-charge in-kind donations to a given organisation (e.g. equipment, in-house products);

- free services - services rendered to a given organisation. This form of assistance does not require the enterprise to engage additional financial means, allowing it to employ company resources that are not used at the time (e.g. an office or appliances);

- pay-roll - employees can make monthly donations of a specified amount for a social purpose of their choice with the amount being deducted from their remuneration individually or through an organisation that provides services in donation distribution. This form of support does not affect benefactors significantly (most often, only an amount exceeding the specified level of pay is deducted) and ensures a stable source of regular income for beneficiaries. Companies may decide to support pay-roll activities undertaken by their employees (e.g. by multiplying the funds collected by employees) - this form of support is called 'matching funds';

- corporate volunteering - the knowledge and skills of company employees are used in initiatives they undertake for local communities (i.e. work for non-governmental organisations and public institutions). Corporate volunteering may cover various types of work, both general 
and expert, undertaken for the supported organisations. The undertaken measures may be one-time actions or systematic initiatives.

\section{Community involvement and its conditioning in pharmaceutical companies in Poland}

Pharmaceutical companies operate in a turbulent environment, which requires them to undertake decisions that would allow them to adapt to these conditions. Maintaining proper relations with local communities is essential for building positive image of pharmaceutical companies, as well as for winning social acceptance for their business operations. Participation in the life of the local community, as well as improvement and enrichment of this life are requirements that modern organisations are obligated to meet.

According to the report titled Wkład innowacyjnego przemysłu farmaceutycznego w rozwój polskiej gospodarki (The contribution of the pharmaceutical industry to the development of the Polish economy) prepared by PwC, Poland is the sixth largest pharmaceutical market in Europe (PwC, 2011). The estimated value of the pharmaceutical market in Poland in 2014 was PLN 22 billion (DELab UW, PZPPF, 2015). In 2010, the national drug production contributed to $1 \%$ PKB (over PLN 15 billion). This market is largely based on the production of generic drugs, i.e. equivalents to brand-name medicinal products that have the very same properties as the original pharmaceutical drugs. Poland is one of major producers of this type of drugs in Europe. The prevalence of generics in national production requires import of innovative drugs protected by patents, making Poland one of the most import-dependent countries within the EU-28 (DELab UW, PZPPF, 2015). In 2010, domestic sales of pharmaceutical companies operating in Poland reached over 714.4 million packages of drugs with the estimated total value of PLN 5.9 billion (Research Institute on Market Economy, nd).

The conformation of pharmaceutical companies to European and national requirements combined with the imposition of administrative fees lead to a continuously growing production and operating costs. Pharmaceutical industry is considered a high-tech industry and hence, a creator of a demand for services provided by research and development entities. Thus, it contributes to the growing innovativeness in the Polish economy (over $7 \%$ of the expenditure on research and 
development comes from the pharmaceutical industry) (DELab UW, PZPPF, 2015).

The high level of technological development of the pharmaceutical industry requires employing qualified staff whose education exceeds that notable of other branches of economy. According to data published in the report titled Makroekonomiczne aspekty znaczenia sektora farmaceutycznego dla polskiej gospodarki (Macroeconomic aspects of the role of the pharmaceutical sector for the Polish economy), about 23 thousand people are employed in the pharmaceutical industry, which accounts for 1-3 per mile employed in the entire economy. The number of people employed in companies related to this industry is estimated at approximately 12.3 thousand. Specialist qualifications required for working in this industry translate into a higher average pay in this sector. Since part of production facilities are located in towns with high unemployment rates, pharmaceutical companies play a significant role as employers in local communities.

In 2010 IMS Health published a ranking of TOP 30 corporations in the pharmaceutical market, according to which the listed companies generate over $82.7 \%$ of the total value of the entire pharmaceutical market in Poland (the remaining $17.3 \%$ being produced by ab. 415 companies) (PwC, 2011). The author analysed contents published on websites of the pharmaceutical companies listed in the TOP 30 ranking (Figure 1) in order to identify community involvement initiatives undertaken by these enterprises, as well as the strategies for communicating social responsibility. If no information on community involvement was published on a given company website, the author conducted additional online research with the use of subject terms by means of Google Search. Due to the accepted local nature of the study, the analysis involved only Polish-language websites.

Websites are not the only source of information about social responsibility initiatives carried out by pharmaceutical companies. Tools used for communicating are, i.a. social reports that contain non-financial data concerning the following fields: environmental, social, and corporate governance. Reports are produced to address the growing social expectations regarding transparency of actions taken by entrepreneurs. The number of published reports is increasing systematically, though social reporting is still considered a new field in Poland. According to the report titled Wspólna odpowiedzialność: Rola raportowania społecznego (Shared responsibility: The role of social reporting), the weakness 


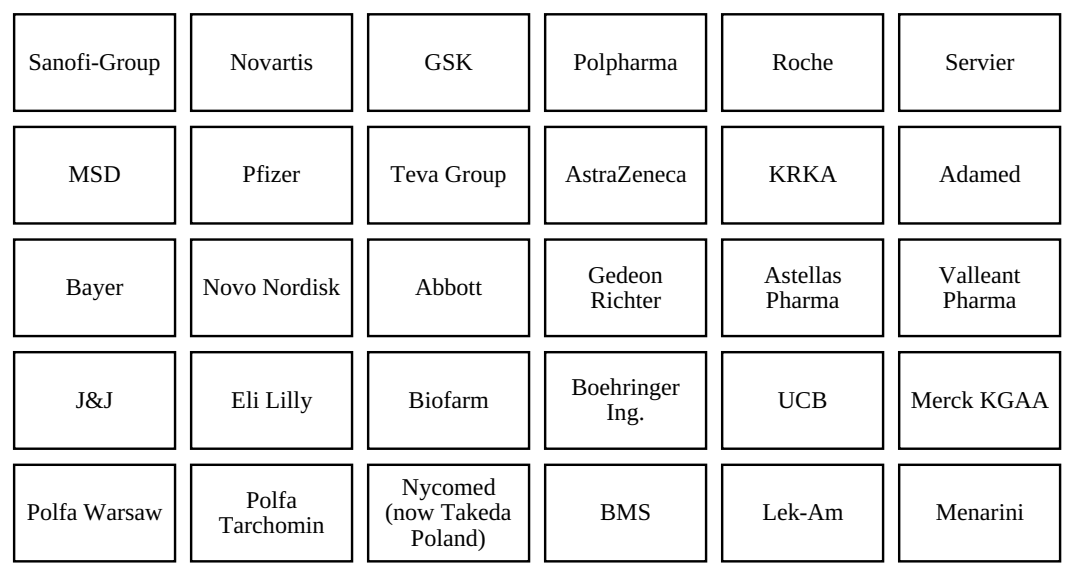

Figure 1. TOP 30 corporations in the pharmaceutical market in Poland in 2010.

Source: own work based on IMS Health, national figures 05/2011, net producer prices (PLN). Pharmaceutical market (OTC medications were not included). Retrieved from http://www.pwc.pl/pl/publikacje/pwc_wklad_innowacyjnego_przemyslu_farmaceutycznego_w_rozwoj_polskiej_gospodarki.pdf (accessed 07 May 2016).

of this type of publications lies in their credibility and reliability, as it is impossible to verify the validity of the published data (Responsible Business Forum, 2013). Critics of this tool also fault it for serving as an image brochure and not for providing reliable data on the actual impact of a given company in the social, environmental, and economic aspect to the interested parties. The author decided to use websites in her analysis, since of all the 30 companies listed as the TOP 30 corporations in the pharmaceutical market in Poland in 2010 only 3 companies published a social report on their websites.

Among the surveyed 30 businesses, websites of 4 companies did not include a section dedicated to corporate social responsibility, whereas 5 companies published information on CCI only on a company website in a language other than Polish (due to the local character of this study these websites were not included in the analysis). Websites of 21 pharmaceutical companies were qualified for further analysis.

In the studied pharmaceutical companies, the most commonly communicated forms of community involvement are:

- financial support - all 21 enterprises subjected to the study provided information on offered financial support. In most cases, donations were provided to non-governmental organisations, aid institutions and 
cultural institutions, patients associations; 11 pharmaceutical companies published on their websites detailed lists of supported organisations with specified amount of donations;

- aid in-kind - 13 companies subjected to analysis declared providing aid in-kind, which involved donation in the form of educational materials, medical equipment, medications, computer equipment;

- corporate volunteering - 12 pharmaceutical companies provided information on corporate volunteering being used. Their employees were most often taking measures for children from orphanages, supported and organised local blood donor sessions or charity runs. For instance, Polpharma company organises annual grant competitions, in which 20 most interesting projects subjected by employees are provided with financial support;

- education campaigns - measures taken by pharmaceutical companies should aim at improving patients' health. As many as 18 companies subjected to the study organised or co-organised education campaigns focused on solving specific health issues existing in the society.

\section{Communication of community involvement initiatives}

Communication of community involvement initiatives demonstrates willingness of companies to share not only their economic results but also the measures taken for local stakeholders. The provided information on conducted community involvement initiatives creates a climate of trust in the external environment of a given enterprise, which contributes to building connections with its stakeholders and in the case of a crisis situation allows for mitigating its negative consequences.

Morsing and Schultz distinguish 3 types of strategies for communicating social responsibility (Morsing and Schultz, 2006, pp. 326-328):

- the stakeholder information strategy - a one-direction communication; the company informs its stakeholders on the undertaken measures in the field of social responsibility. The aim of this strategy is to disseminate information. The stakeholders react to the received information (by supporting the undertaken measures or rejecting them);

- the stakeholder response strategy - a bi-directional communication with an asymmetric flow of information (due to the prevailing number of messages issued by the company). In this model, the enterprise attempts to affect the attitude and behaviour of its stakeholders. The 
information from stakeholders is considered by the enterprise as feedback on the extent to which conducted activities are accepted;

- the stakeholder involvement strategy - a bi-directional communication with a symmetrical flow of information based on a two-way dialogue and active participation of stakeholders.

Informing of the initiatives undertaken in the area of corporate community involvement by means of contents published on websites of all the 21 companies subjected to the study constitutes an example of informative communication. The published data are informative, and the aim of publishing these data is to familiarise stakeholders with the measures taken by a given company with respect to CCI. Individual websites vary substantially in terms of specificity of the data contained therein. On most websites subjected to the study, the nature of the published information pertaining to social responsibility is general and terse.

\section{Discussion and conclusion}

The BI-NGO index is a cyclical study started in 2007, aiming at verifying the methods for communicating efforts in CSR and community involvement employed by 500 largest Polish companies listed by the daily newspaper Rzeczpospolita. The study involves information published on websites and social networking platforms of companies in 5 major areas (SGS Polska, 2014):

- company policy and leadership - this area pertains to evaluating whether community involvement of a given company is inscribed in its mission and vision, and whether the company has other documents on CSR;

- community involvement strategy - whether an organisation has a community involvement strategy published on its website;

- building relations - whether a company informs about the methods and the rules of collaborating with social partners;

- financial transparency and performance measurement - whether a company conducts performance measurement with regard to the undertaken social responsibility initiatives and publishes factual and financial reports on its activities;

- communication - whether websites of the company subjected to the study contain a separate section on corporate community involvement. 
When analysing published BI-NGO index reports (reports from 2007, 2010 and 2014), one may notice a change in communicating community involvement. Measures taken by companies become increasingly better communicated, though most businesses have not reached their full potential in this regard (CSR Consulting, 2011). In 2014, 66\% surveyed companies informed of their community involvement on the Internet. Sections pertaining to community involvement on the websites of analysed companies are complemented to a small degree. This might result from, first of all, the benefits of publishing this kind of information going unnoticed by the management, and second of all, the concern about being accused of using community involvement initiatives for marketing purposes (IE School of Communication, 2010). The authors of the BI-NGO 2010 index highlight the fragmented state of the data provided on websites, which does not contribute to improving company reputation. The leading positions in the BI-NGO 2014 index (companies with total score of at least 85\%) involve no businesses from the pharmaceutical industry.

Griffin distinguishes four types of attitudes towards corporate social responsibility exhibited by companies (Griffin, 2001, pp. 151-154):

- obstructionist stance - the organisation engages in solving community and environmental issues to a limited extent;

- defensive stance - the company implements all responsibilities required by law without taking any additional initiatives;

- accommodative stance - the organisation meets all basic legal and ethical obligations, and also decides to undertake additional measures;

- proactive stance - the highest possible degree of corporate involvement, which involves active work towards contributing to the benefit of society;

The concept of CSR assumes that an enterprise is not an independent autonomous unit but constitutes an integral part of the society in which it operates. The society not only considers a company as a supplier of goods and services but also focuses more and more attention on ethical issues. At present, involvement in social matters is a requirement organisations are expected to meet. Being aware of these expectations, companies decide to take various forms of community involvement initiatives. Those that undertake action only under pressure from the public may see the concept of social responsibility as a sad duty. Sceptics of CSR state that undertaking community involvement initiatives is a type of action oriented at public relations 
and serves merely for improving reputation of a company among its stakeholders.

According to Kotler, undertaking pro-social activities is one of the most stable forms that allows a company to stand out on the market (Kotler, 1998, p. 180). Developing a positive image among local communities makes business operations of a given company more tolerable. Nevertheless, one ought to bear in mind that in extreme cases such an approval may lead to abuse on the part of companies that enjoy social trust (which is particularly important in the case of producers of medications and medical devices - here, patients' lives and health is the highest priority).

Pharmaceutical companies conduct their business activity in a specific social space by using its resources (i.e. infrastructure, human resources) and making their products (i.e. medications, medical devices) within that space, they should therefore actively seek social interest, so that they may consciously shape positive relations together.

The review of 21 websites of the pharmaceutical companies subjected to the study with regard to their community involvement led the author to the following conclusions:

- financial support is the most commonly applied form of community involvement - all companies included in the study declare to offer this kind of support (in most cases in the form of donations). Only 7 companies of all the analysed use 3 forms of support simultaneously (financial support, aid in-kind, corporate volunteering);

- the content regarding community involvement published on the majority of analysed websites are terse and general (e.g. engaging in helping local communities, supporting patients associations). This form of communication does not contribute to building positive relations with stakeholders. A brief mention of undertaken initiatives allows stakeholders to assume that such a company is not interested in a dialogue with local community, which does not contribute to building mutual trust and cooperation;

- sections dedicated to community involvement are not systematically updated. In some cases, the content was last updated in 2014 or 2015. Out of date links present on a given website (in most cases these refer to websites dedicated to education campaigns implemented in the past by a given company) do not contribute to building a positive image of a given company as a partner interested in pro-social activities; 
- only 4 pharmaceutical companies published on their websites comprehensive information on methods and possibilities of receiving support. In order to formulate and enforce fulfilment of expectations that society demands of organisations, it is vital that this idea is familiar to the community. Here, an important role can be played by non-governmental organisations, which support companies in identifying social issues and encourage them to take action. The dialogue between pharmaceutical businesses and non-governmental organisations increase the chance of better adjustment to problems faced by local communities;

- communication of community involvement initiatives in the companies subjected to the study is one-directional (the stakeholder information strategy). Companies inform stakeholders about their initiatives, yet the latter remain uninvolved in the implementation of these actions (there is no dialogue between the company and its stakeholders).

In the Edelman Trust Barometer (2016) survey, 80\% of respondents stated business, apart from generating profit, ought to contribute to the solving of social and economic problems (hence it is so important that companies undertake community involvement initiatives). An opposite opinion was expressed by representatives of companies operating in Poland, according to whom customer relationship (74\%) and employee relationship (72\%) are particularly important for the development of an organisation, whereas the area of community involvement was indicated by only $11 \%$ of the surveyed entrepreneurs (Millward Brown SMG/ KRC and PwC, 2011).

The barriers to community involvement initiatives listed by entrepreneurs include additional financial effort related to such actions. However, in the case of the studied pharmaceutical companies, financial contribution is one of the most commonly chosen forms of assistance. The reason for this lies in the fact that it is a relatively simple form of support which does not require from an organisation any additional effort or time-consuming operations.

The reason for low-level engagement of pharmaceutical companies in actions for local communities may lie in legal barriers, since the complexity and inconsistence of binding legal regulations are not encouraging to undertake time-consuming operations that would allow for acting under the applicable laws. A simplification of such regulations could facilitate and encourage companies to undertake such actions.

Lastly, the insufficient familiarity with community involvement, unawareness of the possible benefits a company may derive from 
using it among the management contribute to the largely one-time nature of actions taken by pharmaceutical companies, instead of being a manifestation of coherent, thoroughly considered long-term strategy. Raising awareness concerning the benefits of the effect of synergy in cooperating with the interested party, i.e. a local community, will make it possible to avoid situations where pharmaceutical companies treat such actions solely as a tool for improving their image.

The concept of social responsibility constitutes a significant element in creating a favourable climate for cooperation between a business and its stakeholders. A declaration of conducting social responsibility initiatives by a company is a commitment made on a voluntary basis. Community involvement initiatives may be used by companies as a tool for winning customers' trust and maintaining best relations with them by building a positive company image, which can consequently improve sales and profit.

\section{Bibliography}

CSR Consulting (2011), “Indeks BI-NGO 2010”. Retrieved from http://odpowiedzialnybiznes.pl/public/files/BINGO_CSRConsulting_2010.pdf (accessed 10 June 2016).

DELab UW, PZPPF (2015), "Makroekonomiczne aspekty znaczenia sektora farmaceutycznego dla polskiej gospodarki”. Retrieved from http://www.delab.uw.edu. pl/wp-content/uploads/2015/11/DELab_Raport_Farmaceutyczny_1.pdf (accessed 17 March 2017).

Edelman (2016), “Edelman Trust Barometer 2016”. Retrieved from http://www.edelman.com/insights/intellectual-property/2016-edelman-trust-barometer/global-results/ (accessed 25 January 2017).

Foundation for Social Communication (2003), “Komunikowanie na rzecz CSR”. Retrieved from http://www.fks.org.pl/raporty/Raport-CSR.pdf (accessed 05 May 2016).

Gołaszewska-Kaczan, U. (2009), Zaangażowanie społeczne przedsiębiorstwa, Uniwersytet w Białymstoku, Białystok.

Griffin, R.W. (2001), Podstawy zarzq̨dzania organizacjami, PWN, Warszawa.

IE School of Communication (2010), "CSR Communication: Exploring European Cross-national Differences and Tendencies”. Retrieved from http://odpowiedzialnybiznes.pl/public/files/CSRCommunication_IE_School_of_communication_2010. pdf (accessed 15 June 2016).

Koneczna, R. (2014), CSR i jego narzędzia jako element strategii firm - praktyczny przewodnik, Wydawnictwo IGSMiE PAN, Kraków.

Kotler, P. (1998), “Konkurencyjność a charakter społeczny”, in: Hesselbein, F., Golgsmith, M., Beckhard, R. (Eds.), Organizacja przyszłości , Business Press, Warszawa. 
Millward Brown SMG/KRC and PwC (2011), “Ocena stanu wdrażania standardów społecznej odpowiedzialności biznesu”. Retrieved from http://badania.parp.gov.pl/ files/74/75/77/13079.pdf (accessed 20 January 2016).

Morsing, M., Schultz, M. (2006), “Corporate Social Responsibility Communication: Stakeholder Information, Response and Involvement Strategies”, Business Ethics: A European Review, Vol. 15, No. 4, pp. 326-328.

PwC (2011), "Wkład innowacyjnego przemysłu farmaceutycznego w rozwój polskiej Gospodarki”. Retrieved from http://www.pwc.pl/pl/publikacje/pwc_wklad_ innowacyjnego_przemyslu_farmaceutycznego_w_rozwoj_polskiej_gospodarki. pdf (accessed 07 May 2016).

Research Institute on Market Economy (nd) “Znaczenie sektora farmaceutycznego dla polskiej gospodarki”. Retrieved from http://www.producencilekow.pl/images/ raporty/Raport_IBNGR.pdf (accessed 20 January 2017).

Responsible Business Forum (2013), “Wspólna odpowiedzialność: Rola raportowania społecznego” Retrieved from http://odpowiedzialnybiznes.pl/public/files/Wspol na\%20odpowiedzialnosc_Raportowanie\%20spoleczne-PODGLAD.pdf (accessed 20 January 2017).

Rok, B. (2004), Odpowiedzialny biznes $w$ nieodpowiedzialnym świecie, FOB, Warszawa.

Rudnicka, A. (2010), “Społeczne zaangażowanie przedsiębiorstw we współpracy z organizacjami pozarządowymi w Polsce”, in: Pisz, Z., Rojek-Nowosielska, M. (Eds.), Społeczna odpowiedzialność organizacji: Perspektywa badacza i wyzwania praktyczne, Wydawnictwo Uniwersytetu Ekonomicznego we Wrocławiu, Wrocław, pp. 110-122.

SGS Polska (2014), “Indeks BI-NGO 2014”. Retrieved from http://www.doradztwocsr. pl/pdf/ULOTKA_BI-NGO_2014.pdf (accessed 10 June 2016).

Sikorska, M. (2010), “CSR w Polsce. Forum UNDP. Zarządzanie zasobami ludzkimi”, in: Kochanowicz, J., Marody, M. (Eds.), Kultura i gospodarka, Wydawnictwo Naukowe Scholar, Warszawa. 